\title{
РЕЗУЛЬТАТЫ КОМПЛЕКСНОГО МОНИТОРИНГА АВАРИЙНОЙ ЗОНЫ НА СКРУ-2
}

\author{
М.М. Калашникова \\ Горнылй институт УрО РАН, г. Пермь
}

\begin{abstract}
Аннотация: В пределах аварийного участка шахтного поля рудника СКРУ-2 выполняются следующие виды мониторинга: сейсмологический, режимный геофизический (сейсморазведка и электроразведка), гидрогеологический, включающий контроль водопритоков в рудник, газогеохимический и инструментальные маркшейдерские наблюдения за оседаниями земной поверхности. В статье представлены результаты мониторинговых исследований на подработанной территории аварийного участка.
\end{abstract}

Ключевые слова: малоглубинная сейсморазведка, интерпретации сейсморазведочных данных, осложнения волнового поля, мониторинг.

В пределах аварийного участка шахтного поля рудника СКРУ-2 выполняются следующие виды мониторинга: сейсмологический, режимный геофизический (сейсморазведка и электроразведка), гидрогеологический, включающий контроль водопритоков в рудник, газогеохимический и инструментальные маркшейдерские наблюдения за оседаниями земной поверхности.

Участок аварии находится в пределах достаточно сложной в геологическом отношении территории [2].

В 2019 году, с целью контроля изменений состояния горного массива ежемесячно проводились сейсморазведочные наблюдения. В пределах аварийного участка развернута сеть из 12-ти профильных линий (рис. 1). Реализованы продольные и непродольные системы регистрации с разнесением линий возбуждения и приема по разные стороны от провала. Непродольные профили спроектированы, исходя из необходимости расположения линий общих глубинных точек непосредственно через проблемную зону в двух взаимно-перпендикулярных плоскостях разреза.

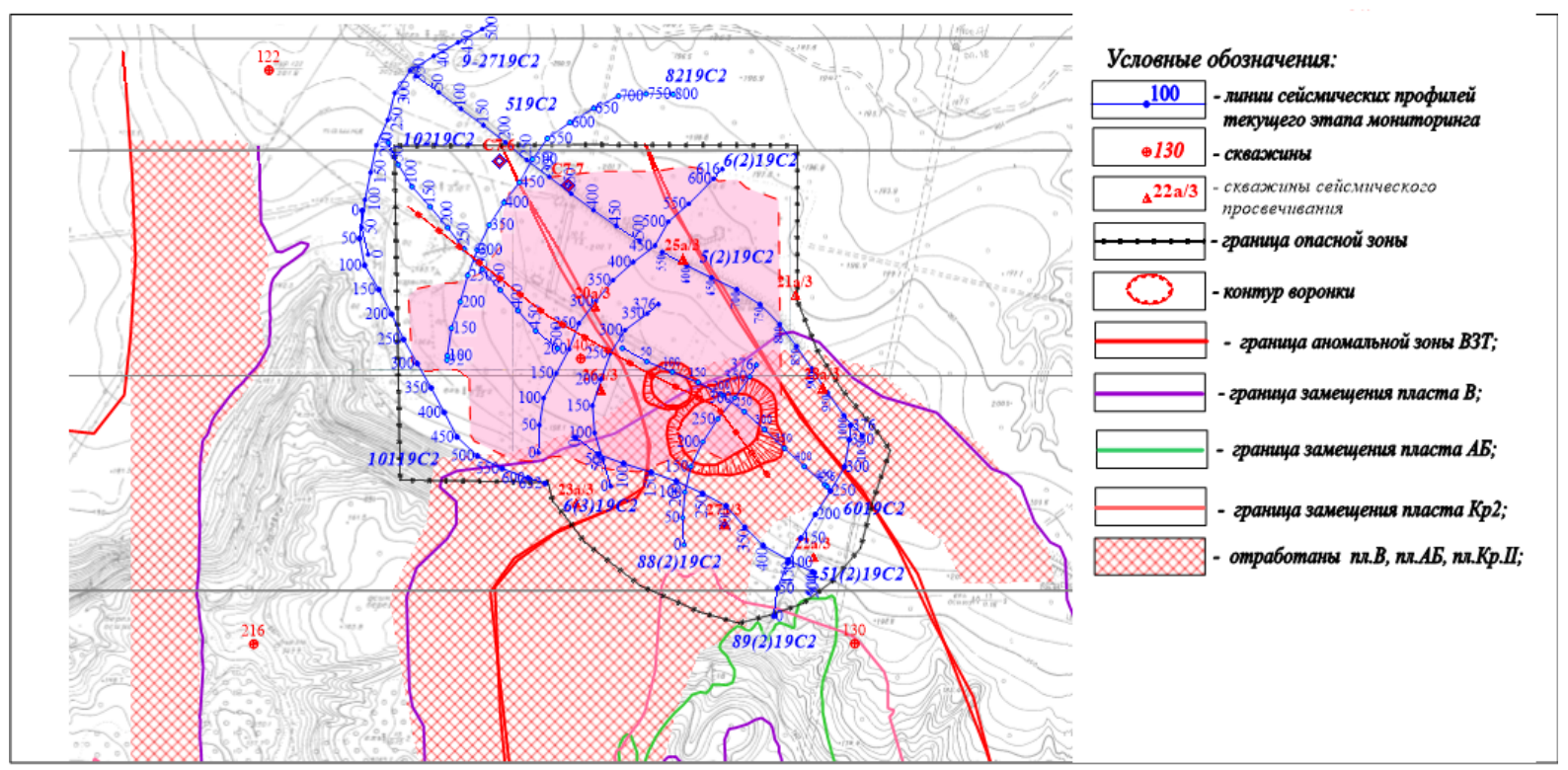

Рис. 1. Обзорная схема района работ

По результатам цифровой обработки и интерпретации на окончательных временных разрезах выделен ряд отражающих горизонтов (ОГ). Они в соответствии с результата- 
ми скоростного анализа и геологоразведочными данными приурочены к кровле: пласта известняка в терригенно-карбонатной толще (ТКТ*), соляно-мергельной толщи (CMT), верхним пластам каменной соли в нижней части соляно-мергельной толщи (BC), карналлитового пласта Е (Ек), сильвинитовой пачки (Сил.) и к интервалу маркирующей глины (МГ).

В пределах исследуемого интервала геологического разреза на профильных линиях выделен ряд участков с разного рода осложнениями волнового поля. В качестве основных признаков предполагаемых осложнений геологического разреза рассматриваются: нарушение корреляции отражающих горизонтов, снижение значений эффективных скоростей и повышенное затухание сейсмической записи (рис. 2).
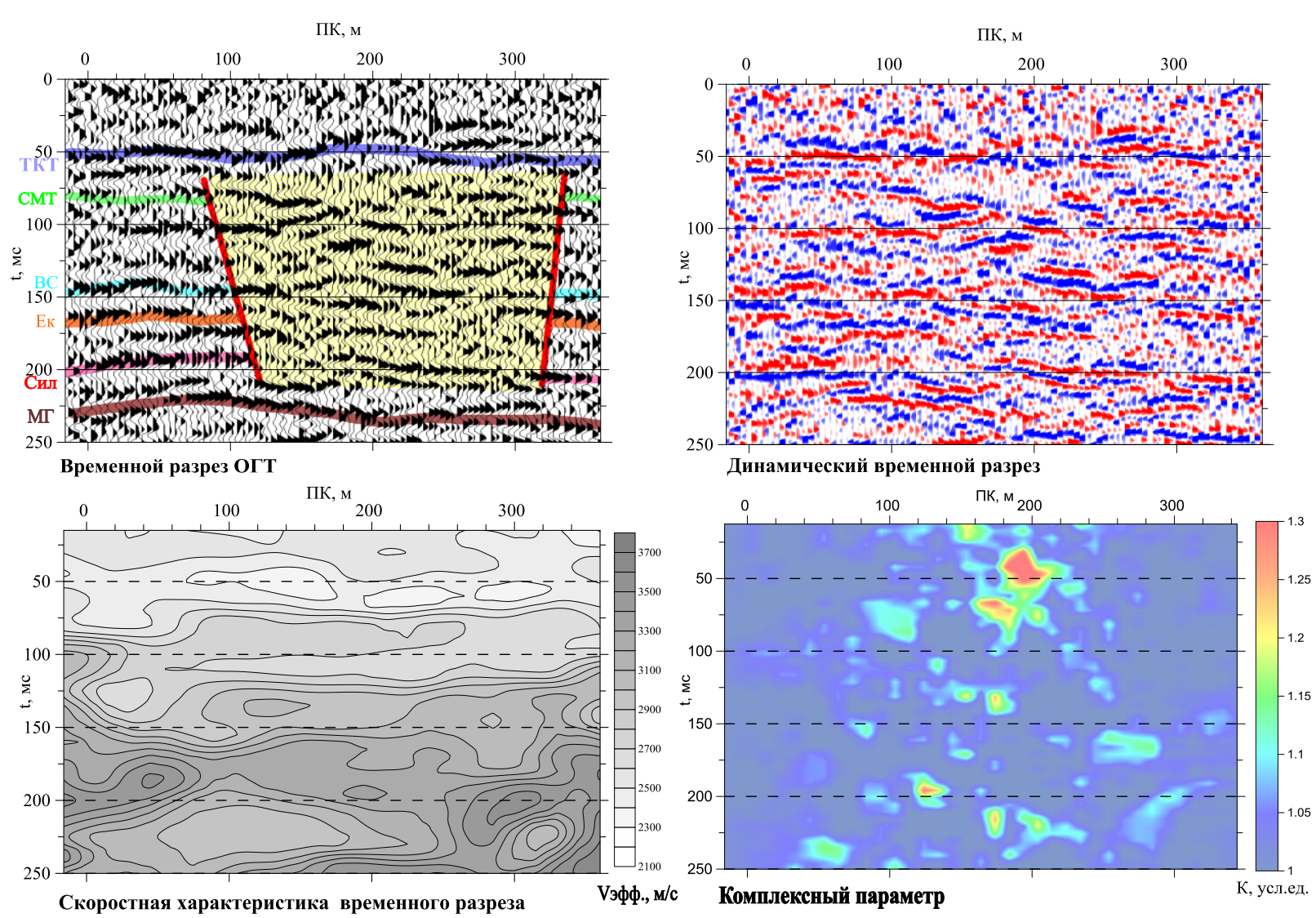

Рис. 2. Результаты цифровой обработки

По результатам цифровой обработки и интерпретации сейсморазведочных данных на предыдущих этапах выделены зоны, связанные с процессами дезинтеграции породного массива. Они объединяются в одну область, вытянутую в северо-западном направлении (рис. 3).

Результаты качественной интерпретации сейсморазведочных данных в основном согласуются с данными сравнительного скоростного анализа за период ноябрь 2018 г. - март 2019 г. (рис. 4). Подтверждается усиление негативных процессов в СМТ в районе скв. 20а и их преобладающее северо-западное направление. В верхней части продуктивной толщи (ВС-Ек) в данном направлении отмечается «уплотнение» отложений, что может носить техногенный характер. В интервале продуктивной толщи, как и ранее, в районе основного провала преобладает северное направление развития негативных изменений и выделяется северо-западный потенциально-опасный участок. 


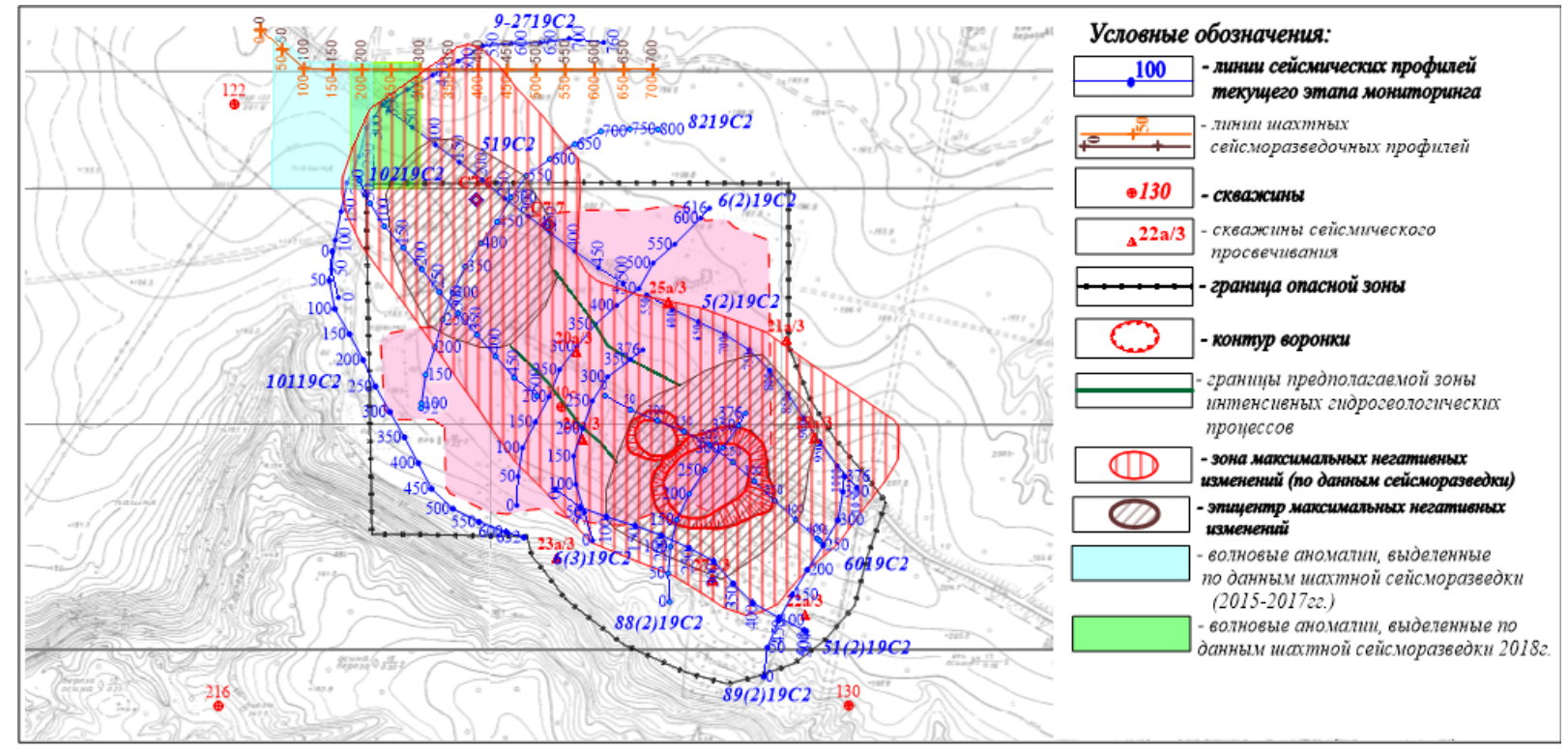

Рис. 3. Схема работ с результатами качественной интерпретации

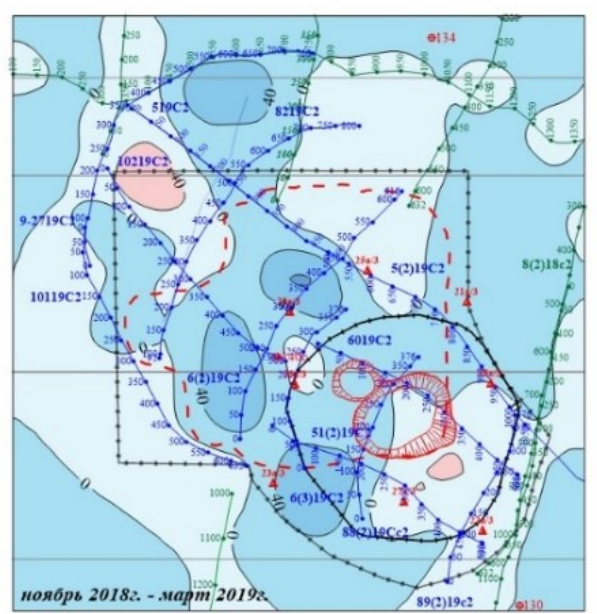

a) $\mathrm{V}$ У

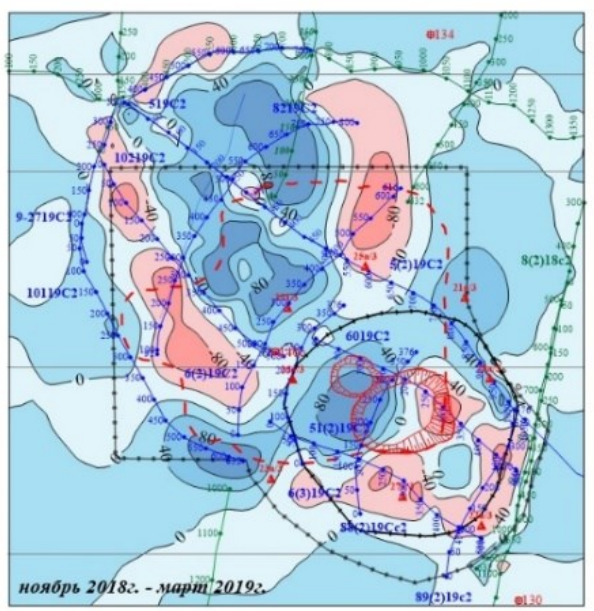

B) V OГ ВC- ОГ ЕK (220 - 260M)

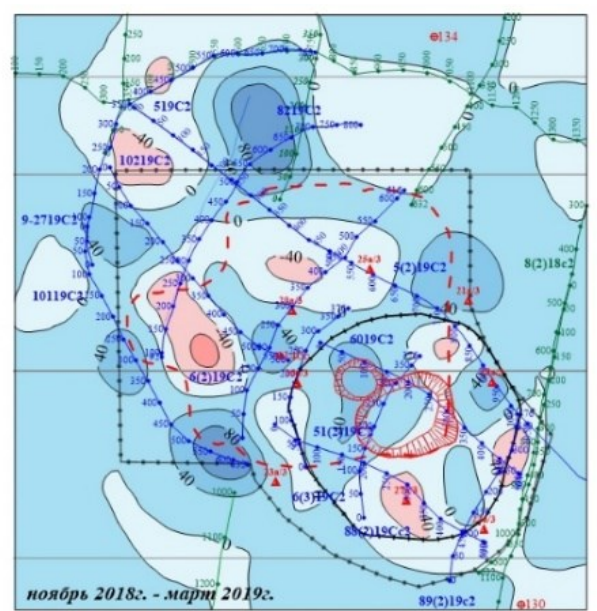

б) V OГ CMT - OГ BC (130 - 220M)

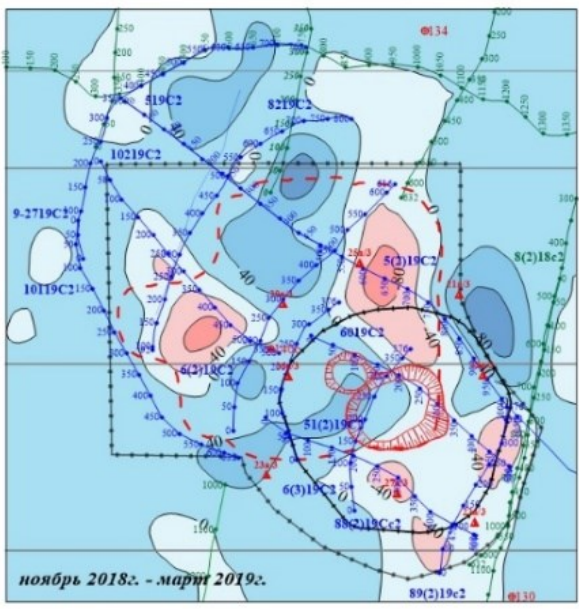

г) V ОГ Ек - ОГ Снл. (260 - 320м)

Рис. 4. Схемы временной изменчивости интервальных скоростей (ноябрь 2018 г. - март 2019 г.)

Микросейсмическая активность в первой половине 2019 г. характеризовалась крайне высокой неравномерностью во времени. Мониторинговой системой было зарегистри- 
ровано свыше 2700 сейсмических событий, связанных с процессами разрушения в горных породах. Все события были связаны с процессами разрушения в слабо консолидированных породах. Эпицентры всех зарегистрированных событий располагались в пределах достаточно компактной зоны, расположенной в северо-западной части контролируемой территории в районе северо-западного края зоны обрушения 1995 г. (рис. 5).
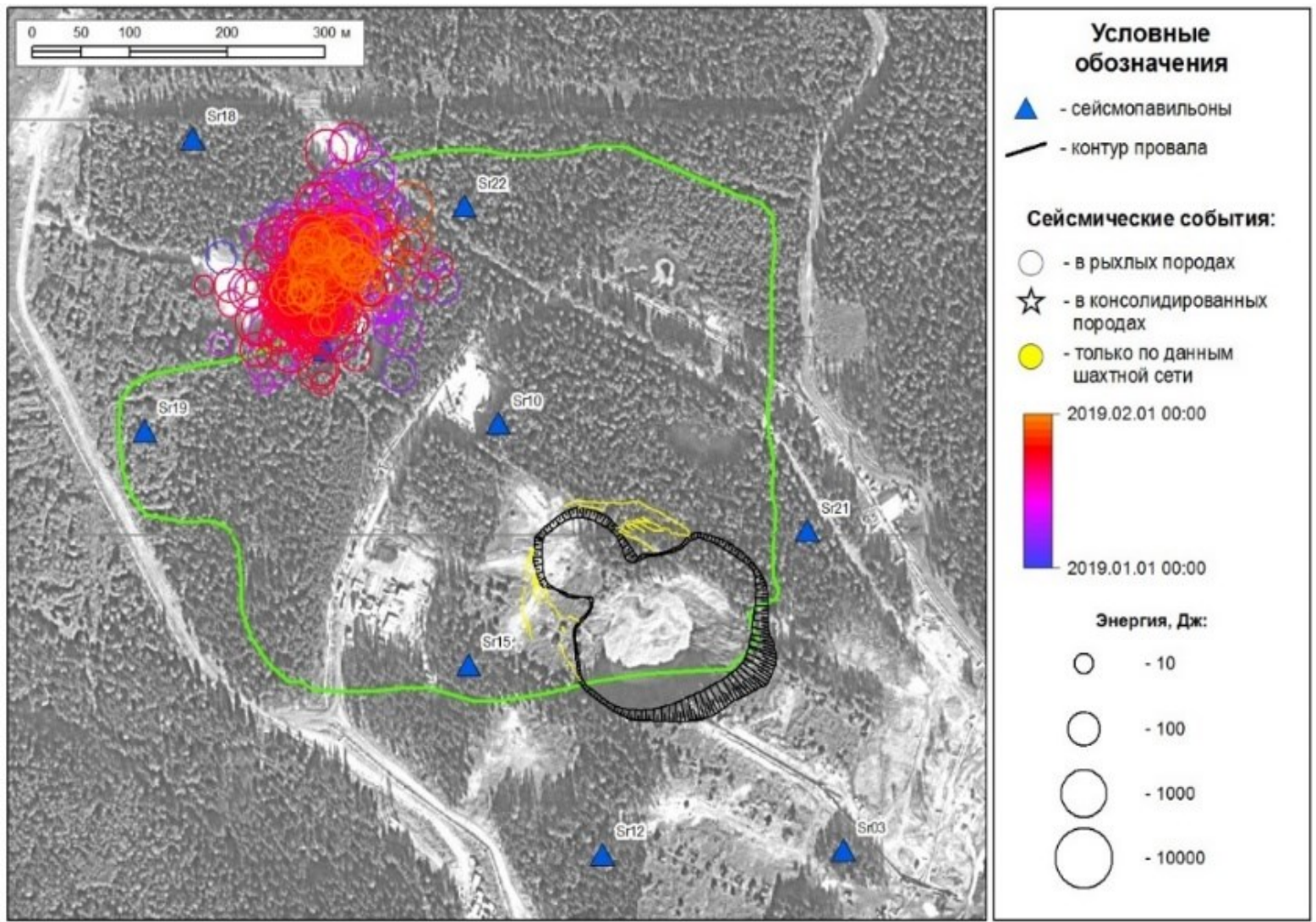

Рис. 5. Схема расположения эпицентров сейсмических событий, зарегистрированных в январе 2019 г.

На дальнейшем этапе мониторинга относительное снижение значений скоростей распространения упругих волн в большинстве исследуемых интервалах геологического разреза отмечается к югу и юго-востоку от провала (рис. 6). Для северо-западного потенциально-опасного участка подобные негативные изменения упругих параметров сосредоточены в интервале продуктивной толщи. Возможно подобное снижение негативной динамики на данном участке обусловлено интенсивным техногенным воздействием на вышележащие интервалы.

Аномально высокий уровень микросейсмической активности, отмечавшийся в декабре 2018 г. - мае 2019 г., в июне сменился заметным спадом. Эта тенденция продолжилась и в третьем квартале 2019 г. Анализируемый период в целом характеризовался весьма низким уровнем микросейсмической активности. Мониторинговой системой было зарегистрировано 21 сейсмическое событие, связанное с процессами разрушения в горных породах (рис. 7).

По результатам наблюдений в ноябре и декабре 2019 г. негативная динамика относительно предыдущих этапов по особенностям волновой картины отмечается только в северо-западной части контролируемой территории. Подобная тенденция преобладания негативных изменений на северо-западе находит подтверждение и при анализе изменчивости количественных оценок скоростей распространения упругих волн в различных интервалах геологического разреза (рис. 8). 


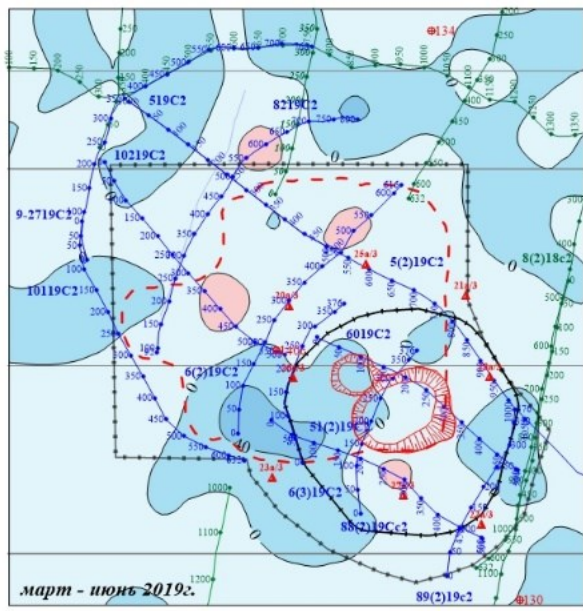

a) V Ур.пр.-ОГ СМТ (30 - 130м)

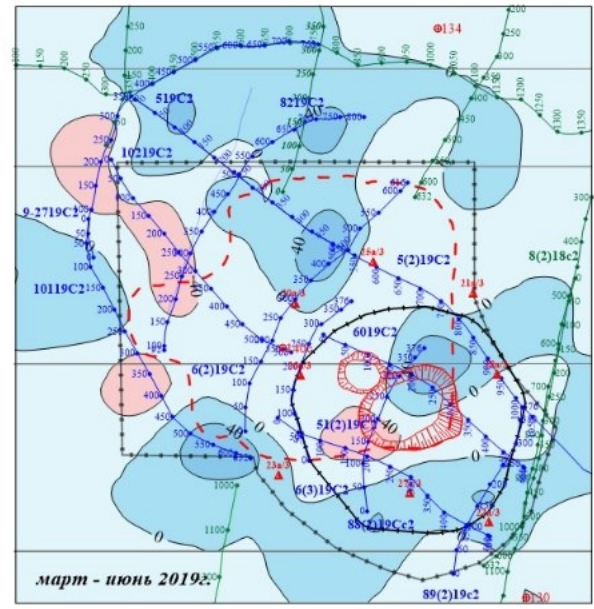

в) V ОГ ВС - ОГ Ек (220 - 260

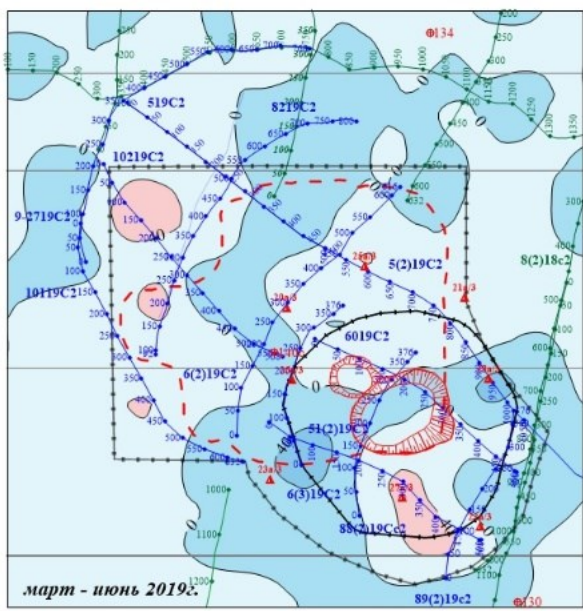

б) V OГ СMT - OГ ВC (130 - 220M)

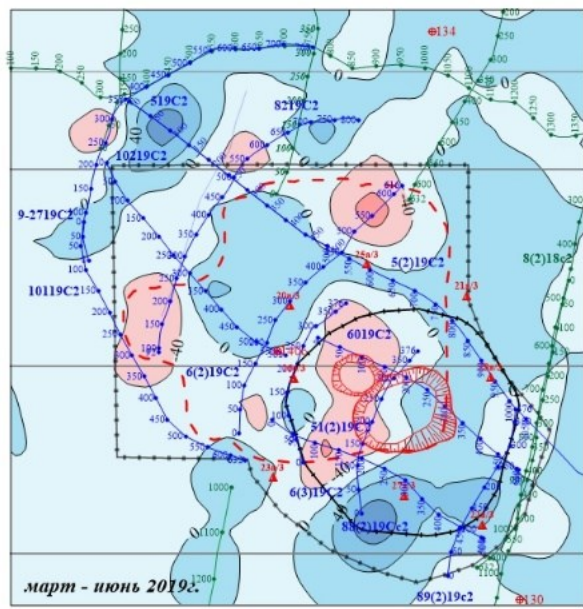

г) V ОГ Ек - ОГ Сил. (260 - 320心)

Рис. 6. Схемы временной изменчивости интервальных скоростей (март - июнь 2019 г.)

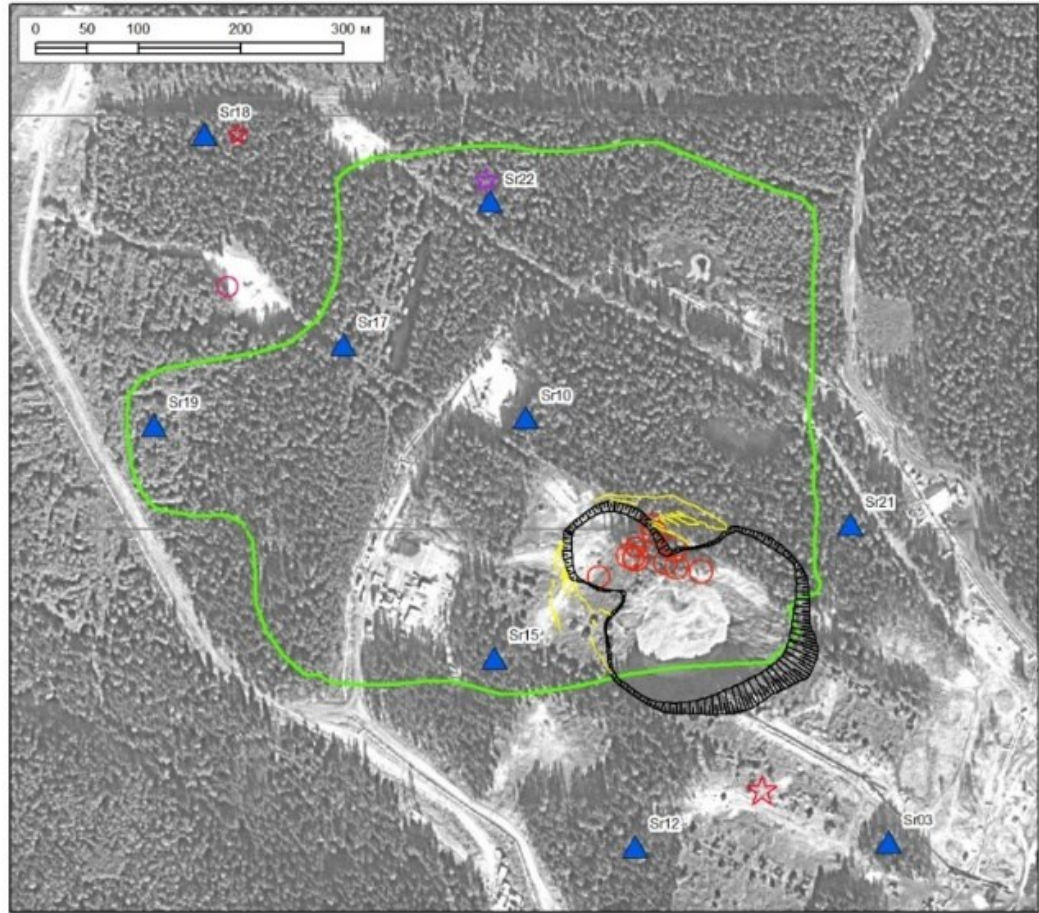

Условные
обозначения
- сейсмопавильоны
- контур провала
Сейсмические события:
- - рыхлых породах
- в консолидированных
породах
- толко по данным
шахтной сети
2019.08.01 00:00
2019.07.01 00:00
Энергия, дж:
-10
-100
-1000

Рис. 7. Схема расположения эпицентров сейсмических событий, зарегистрированных в июле 2019 г. 


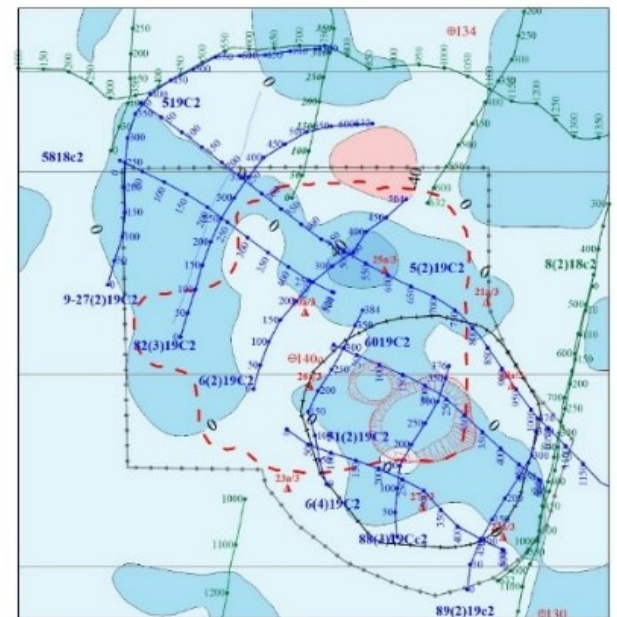

a) V Yp.пp.-OF CMT (30 - 130m)

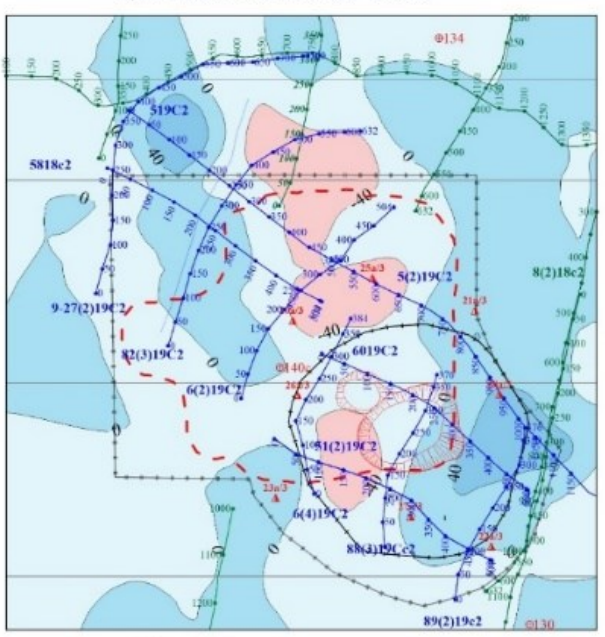

в) V ОГ ВС - ОГ Ек (220 - 260M)

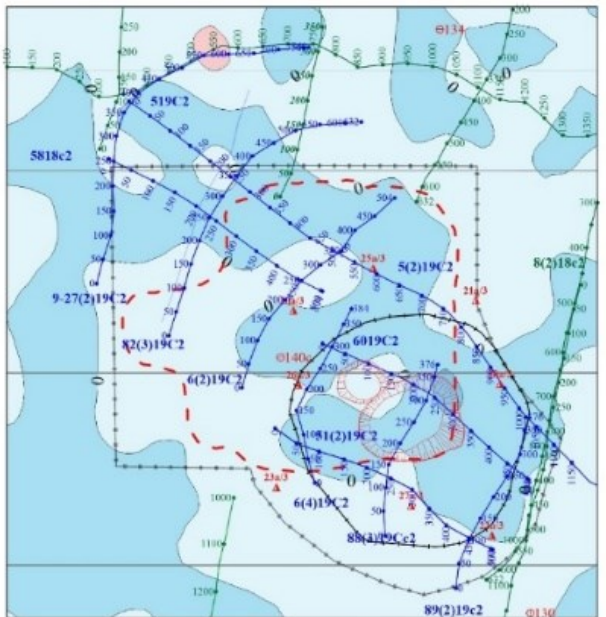

б) V OГ CMT - OГ BC (130 - 220M)

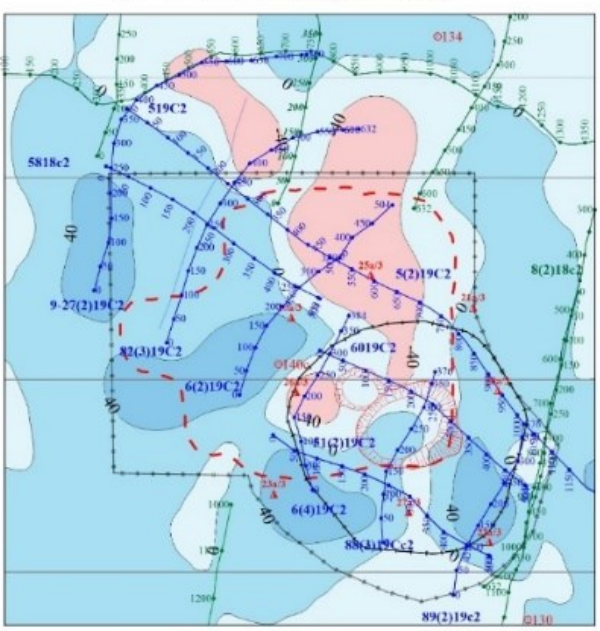

г) V ОГ Ек - ОГ Сил. (260 - 320M)

Рис. 8. Схемы временной изменчивости интервальных скоростей (сентябрь - ноябрь 2019 г.)

По результатам цифровой обработки в течение года корректировались границы выделенной в 2018 г. области северо-западного простирания. В юго-восточной части площади работ выделяются участки с признаками интенсификации негативных гидрогеологических процессов к северо-востоку и востоку от провала. В северо-западной части контролируемой территории негативные изменения волновой картины продолжают отмечаться в центре выделенного на предыдущем этапе участка. Расширились границы эпицентров негативных изменений сейсморазведочных параметров: для юговосточного участка в северо-восточном и юго-западном направлениях и для северозападного участка в северном и юго-западном направлениях.

Исследование выполнено при финансовой поддержке Программы ФНИ, проект № 0422-2019-0146-С-02 (регистрациионный номер темы НИОКТР: AAAA-A18-118040690028-5)

\section{БИБЛИОГРАФИЧЕСКИЙ СПИСОК}

1. Санфиров И.А. Рудничные задачи сейсморазведки МОГТ / ГИ УрО РАН. - Екатеринбург, 1996. $-168 \mathrm{c}$.

2. Петротектонические основы безопасной эксплуатации Верхнекамского месторождения калийномагниевых солей / под ред. Н.М. Джиноридзе. - СПб; Соликамск, 2000. - 400 с. 